\title{
Securing a life for the dead among the Yukpa. The exhumation ritual as a temporary synchronisation of worlds
}

Garantir la vie des morts chez les Yukpa. Le rituel de l'exhumation comme synchronisation temporaire des mondes Asegurar una vida para los muertos entre los yukpas. El ritual de la exhumación como una sincronización temporal de los mundos

\section{Ernst Halbmayer}

\section{OpenEdition \\ Journals}

Édition électronique

URL : https://journals.openedition.org/jsa/12620

DOI : $10.4000 /$ jsa. 12620

ISSN : $1957-7842$

\section{Éditeur}

Société des américanistes

Édition imprimée

Date de publication : 15 septembre 2013

Pagination : 105-140

ISSN : 0037-9174

Référence électronique

Ernst Halbmayer, "Securing a life for the dead among the Yukpa. The exhumation ritual as a temporary synchronisation of worlds ", Journal de la Société des américanistes [En ligne], 99-1 | 2013, mis en ligne le 01 mars 2016, consulté le 02 septembre 2022. URL : http://journals.openedition.org/ jsa/12620 ; DOI : https://doi.org/10.4000/jsa.12620 


\title{
SECURING A LIFE FOR THE DEAD AMONG THE YUKPA. THE EXHUMATION RITUAL AS A TEMPORARY SYNCHRONISATION OF WORLDS
}

\author{
Ernst HALBMAYER *
}

\begin{abstract}
This paper presents a description and analysis of the Yukpa exhumation ritual. The ritual is explained from an alterity-based socio-cosmological point of view based on the assumption that the internal structure of the death ritual only reveals itself if the existence of the co-present worlds of the living and the dead are used as a point of departure together with the concomitant transformative and perspectivist quality of the ritual. The Yukpa secondary burial aims to effect specific changes in the perspectives and relations of the participants and produces a synchronisation between these worlds and thereby facilitates the necessary contact and transition between them. This passage is neither marked by a radical divide between the dead and the living nor by an unbroken continuity, but by a gradual transformation that culminates in a « de-burial» (desentierro) followed by a secondary burial. [Key words: Yukpa, mortuary ritual, secondary burial, myth, land of the death.]
\end{abstract}

Garantir la vie des morts chez les Yukpa. Le rituel de l'exhumation comme synchronisation temporaire des mondes. Cette contribution a comme sujet la description et l'analyse d'un rituel d'exhumation chez les Yukpa. À partir d'un point de vue sociocosmologique, nous posons comme hypothèse que la structure interne de ce rite funéraire se révèle uniquement si nous considérons en même temps la coprésence des mondes des vivants et des morts et la qualité transformante et perspectiviste du rituel. Le deuxième enterrement chez les Yukpa a pour but de provoquer des changements spécifiques dans les relations et les perspectives des participants mais aussi de produire une synchronisation entre les deux mondes pour permettre le contact et la transition entre les deux. Ce passage n'est caractérisé ni par une division radicale entre la mort et la vie, ni par une continuité ininterrompue, mais par une transformation graduelle qui culmine au moment de la fouille de la tombe, laquelle est suivie par un deuxième enterrement. [Mots-clés : Yukpa, rite funéraire, deuxième enterrement, mythe, monde des morts.]

* Institut für Vergleichende Kulturforschung - Kultur-u. Sozialanthropologie und Religionswissenschaft Philipps-Universität Marburg Kugelgasse 10, D-35032 Marburg [halbmaye@staff. uni-marburg.de].

Journal de la Société des Américanistes, 2013, 99-1, pp. 105-140. C Société des Américanistes. 
Asegurar una vida para los muertos entre los yukpas. El ritual de la exhumación como una sincronización temporal de los mundos. Este texto presenta una descripción y un análisis del ritual de exhumación yukpa. El ritual es explicado desde un punto de vista socio-cosmológico. Se asume que la estructura interna del ritual mortuorio sólo se manifiesta si la coexistencia de los mundos de los vivos y los muertos es tomada como punto de partida junto con la concomitante calidad transformativa y perspectivista del ritual. El entierro secundario entre los yukpas tiene como objetivo causar cambios específicos en las relaciones y perspectivas de los participantes y produce una sincronización entre estos mundos facilitando así el contacto necesario y la transición entre ellos. Este pasaje no es marcado por una división radical entre los muertos y los vivos, tampoco por una continuidad ininterrumpida, sino por una transformación gradual que culmina en un desentierro seguido por un entierro secundario. [Palabras claves: yukpas, ritual mortuorio, entierro secundario, mito, mundo de los muertos.]

In this paper I will present data on a central part of the rituals surrounding death as performed by the Yukpa, an indigenous group of Carib-speakers ${ }^{1}$ resident in the border regions of Columbia and Venezuela. My analysis will focus on the fate of the dead after death and deal with the actions and rituals carried out by the living, which are considered to be essential for ensuring the deceased an amiable life among the dead. In doing so, I will draw upon Yukpa narratives about a mythical journey to the realm of the dead and describe and analyse an observed exhumation ritual (ekane ewatpo $)^{2}$.

In 2009 I was able to observe two Yukpa mortuary ceremonies that could not have been more different from one another: one in March among the Columbian Iroka-Yukpa and the other in September among the Venezuelan Irapa-Yukpa (Figure 1). Among the Irapa-Yukpa living near the Capuchin mission Los Ángeles del Tukuko, the death ritual consisted of a Catholic velorio, where the relatives of the deceased held a wake next to an open casket. Coffee, cigarettes and later food were served. Two Capuchin missionaries and three mission nuns were present. The rosary was prayed and the deceased, who due to the great heat was already showing first signs of decomposition, was buried early the next morning, while the wake lasted a total of nine days. The only reminiscences of traditional ideas were the handing out of cigarettes and the remark made by the Yukpa I was accompanying that children should not eat any of the food offered at this occasion as it was nourishment for the deceased and thus dangerous for children. The idea that the living and the dead share food, traditionally maize beer, and that a commensality is produced between the living and the dead during the death rituals is thereby expressed. Among the Iroka-Yukpa in Columbia, on the other hand, I was able to observe a non-christian Yukpa exhumation ritual, which I will describe and analyse in the context of Yukpa socio-cosmological conceptions. 


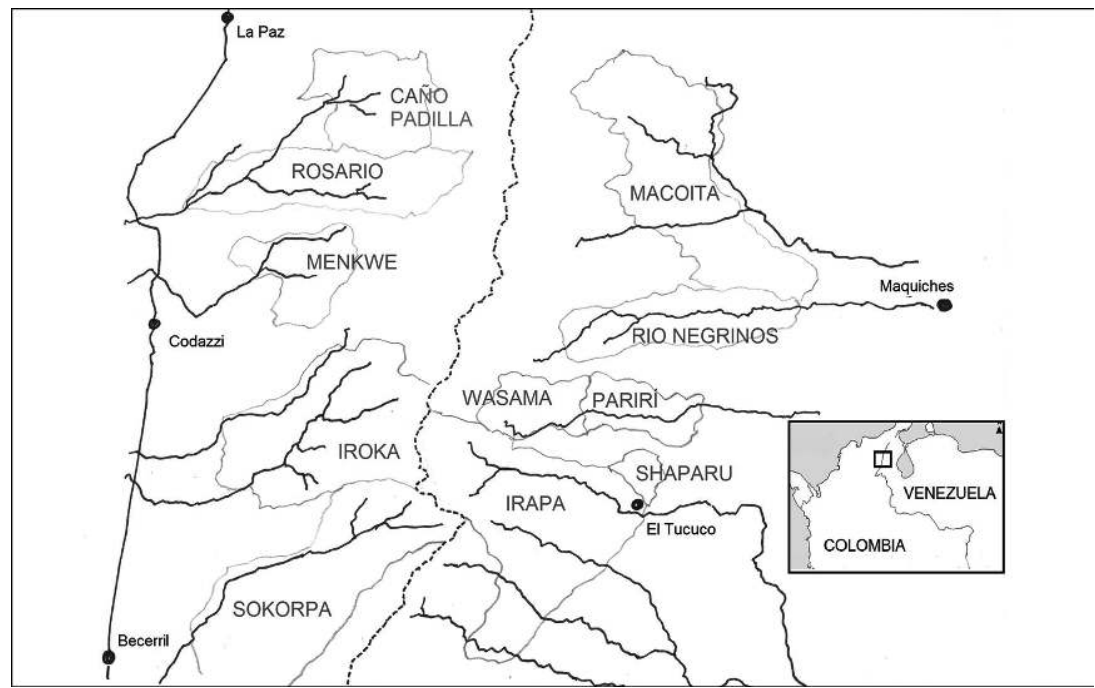

FIG. 1 - Major Yukpa settlement areas.

\section{DISCONTINUITY AND/OR CONTINUITY WITH THE DECEASED}

Since the late 1960s, the dead in Amazonia have been conceived as socio-cosmological enemies (Clastres 1968) or others (Carneiro da Cunha 1978), who may also take on the form of animals and thus become game for the living (Conklin 1993, 1995, 2001; Vilaça 1992, 1993, 2000). But parts of the dead may also be eaten by human enemies or relatives (e.g., Tupinamba, Yanomami, Cashinahua) or by cannibalistic gods (Arawaté) (Viveiros de Castro 1992).

Such concepts have been contrasted with African models (Carneiro da Cunha 1976) that proceed from the assumption of an enduring relationship between the dead and the living and the existence of a corresponding ancestor cult. Taylor (1993, p. 653) specifies the radical discontinuity between the living and the dead found in many lowland South American societies when she writes:

It has become a commonplace of Amazonian ethnology to point out the absence in lowland societies of anything resembling ancestor cults, the shallowness of genealogical memory as well as the paucity and apparent simplicity of most funeral rituals (at least throughout western Amazonia), and the general scarcity of tombs or indeed of any marked spaces durably associated with the dead. Far from stressing continuity with their ancestors and enshrining their memory in names, epics and monuments, lowland Amerindians expend considerable time and ingenuity in losing their dead, forgetting their names and deeds, and emphasizing their remoteness from the world of the living. 
In this understanding, forgetting - or active disremembering - is at the heart of grieving. Among many indigenous Amazonian groups this goes hand in hand with the general unimportance or a radically different concept of genealogical descent (Rivière 1993), a « genealogical amnesia » (Rivière 1984, p. 99) and the particular importance of affinal relationships (e.g., Viveiros de Castro 1993, 2001). Symbolic affinity and concomitant predation are also seen as the central modes of relating to the dead, establishing a « radical discontinuity between the living and the dead » (Taylor 1993, p. 654). At the same time it renders the dead « ever present in the shape of a non-territorialized yet neighbouring social species or tribes » (ibid.).

Yet this supposed radical Amazonian discontinuity can be contrasted with empirical evidence of continuities between the living and the dead. Among the Yukpa for example, no tabu to mention the names of dead persons may be found, no strategies of active disremembering may be identified. Much more, the Yukpa try to stay in contact with the recently deceased, they try to preserve their memory over long periods of time and they conserve the bones of close relatives in their homes over several years or even decades. Reichel-Dolmatoff $(1945$, p. 50) already described how the bones of the deceased travel for years between the houses of close relatives and I could myself observe that for example the skull of a close relative was stored beside the house among the Irapa-Yukpa (Halbmayer 1998, p. 132) or that one old woman of Yurmutu guarded the bones of her children who died at early age among her belongings.

Evaluating existing evidence in Amazonia, Chaumeil (1997, 2007) therefore argues that in lowland Amazonia, two opposing forms of dealing with the dead exist: some groups wish to erase the deceased from their memories whereas others desire to stay in contact with them. For him the Yukpa are an example for the latter and he associates the «stay-in-contact " mode with the «sacred-flute-complex» and the preservation of bones. In the following I will analyse forms of continuity and discontinuity involved in Yukpa mortuary practices.

\section{MYTHS AND RITUALS OF THE PASSAGE INTO THE REALM OF THE DEAD}

Among the Yukpa the ritualised dealings with the dead and the notions expressed in mythical narratives complement one another. Myths and rituals each provide a partial expression of this passage. They throw light on one another without the rites being reducible to myths or ritual actions being merely a repeated enactment of original myths, as Eliade (1949) once argued.

As performances, rituals and myths vary with different protagonists, contexts and situations. They constantly take on new forms. This performative inconsistency and its innovative spirit lead to the creation of multiple and variable 
versions, both of the mythical narratives and the ritual performances. Such versions nevertheless still share a common core of basic concepts and a deep structure of largely constant elements, in which I am interested here. I will regard myths and rituals as structured expressions of underlying socio-cosmological concepts.

The Yukpa myth of the journey into the realm of the dead provides a verbalised description and explanation of the passage between this world and the world of the dead. The ritual, on the other hand, focuses on the expressive performance and creates highly emotional, personal and collective experiences, which are revealed spatially between different participating humans but hardly verbalised.

This ritual does not just take place at the sites where it is visually enacted between living humans, but also in non-visible co-existing places and it engages with co-present but invisible beings. These invisible beings and places deny themselves to direct observation. However, in the context of Yukpa socio-cosmological conceptions, these co-existing worlds and actors play a crucial role and therefore I will attempt to interpret the ritual not just in terms of what may be seen but what culturally competent observers know is there, even if they may not (or not all of them) perceive or see it.

In this ritual, music and dance set the frame for ritual interventions that connect places and worlds and allow for multiple transformations of both the living and the deceased. The people acting in these rituals create, through the monotonous repetition of music and dance and by means of the excessive consumption of alcohol, a special performative and emotional level of experience that reaches beyond the bounds of everyday reality. Therein produced ecstatic forms of expression and connections to the other world all contribute to the ultimate goal of facilitating the passage of the deceased into the world of the dead.

The death ritual dramatises fundamental dichotomies, for example between the living and the dead, between guests and villagers, revellers and mourners or the deceased and other spiritual beings. At the same time it connects, transforms and temporarily dissolves these dichotomies. Thus allowing a ritual convergence and harmonisation of the living and the dead, facilitating the journey from the world of the former into the world of the latter.

My goal in the following is to describe the internal structure of the Yukpa " exhumation ceremony ». This will include concepts as formulated in Yukpa mythology and expressed in ritual. In this process, dimensions of the ritual will be described that are to the best of my knowledge not explicitly and coherently articulated by the Yukpa themselves. The suggested interpretation of the ritual's inner structure is a reconstruction from field observations, background knowledge formulated explicitly in narratives, conversations, and firsthand accounts of the ritual by participants themselves ${ }^{3}$. The interpretation of this 
ritual is, ergo, that of the anthropologist attempting to make sense of an aspect of local Yukpa culture.

As rituals, like myths, have several layers of meaning (Kohl 1992; Münzel 1994), the suggested interpretation does not claim to cover all of them. It focuses on the enacted relation between the living and the dead and contrasts a this-worldly sociological and functionalist understanding of the ritual activities of the living and their treatment of a corpse with an alterity-based sociocosmological interpretation. The ritual communitas (Turner 1969) produced in this ritual connects and includes, so my hypothesis, not only the living participating in the ritual but overcomes - at least temporarily - the divide between the living and the dead and introduces for that purpose new divisions between the living. From this perspective, the ritual's function goes far beyond the social issues and problems immediately associated with the death of a member of the community.

If, as among the Yukpa, an autonomous world of the dead exists, then the primary problem expressed in the myths and rituals, for the living as well as the deceased, is neither that of social loss - of a "partial destruction of social cohesion » - caused by a death (Radcliffe-Brown 1964 [1922]) nor of who inherits a deceased individuals material goods or even of the reassignment of social functions, rights or social status amongst the living (ibid.; Malinowski 1929, 1948; Goody 1962). The central issue that unites the living with the dead is a common interest in the precarious status of the deceased and how their successful passage from one world into another can be guaranteed. This passage is not a matter of course, it does not proceed automatically. Rather, the ritual performance supports and accompanies this passage and represents a central activity of the living for the deceased. The success of this passage is the prerequisite for the deceased being able to continue their peaceful existence in the realm of the dead.

The fate of the dead is not determined by the mere fact of physical death. An analysis of South American mythical concepts of dying reveals in many cases a process, a successive transformation: «With death, [...] a protracted process begins, which is concluded only after a number of transition phases, in a "second death" "(Cipolletti 1982, p. 1, my translation). This transformation starts among the Yukpa with a persons' separation into a corpse (ekane) and a spiritual aspect (okatu), which is central to the process of dying.

Death is intimately related to other events that lead to the separation of discreet spiritual aspects, various doubles or shadows from the body of an individual. Such events include dreams, illnesses and unconsciousness as well as visions induced by the consumption of drugs. Upon death, an individual's spiritual aspect leaves the body as it does in dreams or in cases of illness. Physical death is thus from a local point of view not primarily caused by a failure of bodily functions but by the loss of spiritual aspects and their permanent separation from the body. For the Yukpa the lack of yoramshi - of breath - signals physical death 
and indicates the irreversibility of the mentioned separation. As in many other cultures (Hertz 1907; Barley 1981), the further transformation of the corpse is associated with a process of desiccation and different qualities the spiritual aspects of the deceased assume over time.

Among the Yukpa, the passage from one world to the next is marked neither by a radical divide between the dead and the living nor by an unbroken continuity, but by a gradual transformation that culminates in a collective "de-burial » (desentierro) ritual followed by a rather informal final disposal of the bones ${ }^{4}$. As Reichel-Dolmatoff (1945, p. 62) observed, « the important point is not the secondary burial per se, but the de-burial, the "resurrection" of the deceased, his dance with family members and his sojourn in their homes ». According to Yukpa myth, there once existed the possibility to reverse this process of desiccation and decay and the attaining of eternal life. A myth tells of a dead Yukpa who wished to save his relatives from dying. He brought life-giving and rejuvenating water from the world of the dead to that of the living. When the living washed themselves with this water, they gained the ability to replace their skins and hence became immortal ${ }^{5}$. But the Yukpa refused to do so, unlike certain animals such as snakes (kiripo, especially among them yatama and owataku), scorpions (wasapu), crickets (kürashu) and cockroaches (kishirap). While these animals acquired the means to shed their skins to renew themselves and become immortal in the eyes of the Yukpa ${ }^{6}$, the Yukpa now die irrevocably (Villamañan 1982, p. 19; Halbmayer 1992a, 1992b, 2001a).

This regenerative, life-giving aspect of dying (Bloch and Parry 1982) does not, for humans today, take place in this world but in the world of the dead. There the arriving Yukpa are fed and maize beer is offered by their deceased relatives in a welcome celebration.

Cipolletti (1982) stresses the analogy between this world and the Yukpa world of the dead: «This is the most human-like realm of the dead one can find in the sources in that the dead have no unearthly characteristics; they look like people, live in families, have sexual relations with each other and procreate » (ibid., p. 197, my translation). For the Yukpa, establishing a connection between the world of the living and that of the dead is accompanied by festivities of utmost importance (Wavrin 1953, p. 267).

\section{THE SPIRITUAL ASPECTS OF PERSONS}

Contrary to numerous other Amerindian cultures, the Yukpa recognise only one single spiritual aspect (okatu) in a person ${ }^{7}$. This spiritual aspect is considered to be not only the spirit of the deceased but also an integral part of the once living person. Among a great number of other Carib-speaking (i.e. Yekuana, Arara) and other groups of lowland Amazonia (see McCallum 1999 on 
the Cashinahua; Mader 1999, 2002 on the Shuar; Illius 1991 on the Shipibo), there exist multiple spiritual aspects of a person, which may also have different eschatological fates, stand in relation to different levels of the cosmos and often transform into various beings immediately after death ${ }^{8}$. In contrast, among the Yukpa, after physical death the single spiritual aspect of the person takes on various qualities and characteristics over the course of time, analogous to the transformation of the body.

The Yukpa notion of the spiritual unity of the deceased is attended by efforts to preserve his or her physical unity. Traditionally, strategies of mummification by means of air drying and smoking were applied to prevent that « the flesh will get lost », as the Yukpa say ${ }^{9}$. This endeavour to preserve the integrity of the body contrasts the selective incorporation of parts of a corpse as practised by numerous other Amazonian groups. The Yukpa strive to prevent precisely such an incorporation through consumption. They engage neither in exo- nor endo-cannibalism ${ }^{10}$, nor should animals or spiritual beings take possession of the dead. The dead are not transformed into game and do not become food for the living.

Only enemies killed in battle, yuko, were to be consumed, however not by humans. Enemies were not buried but left to be eaten by the vultures, and were viewed as a kind of sacrifice to the sun and its mythical attendant, the vulture ${ }^{11}$. Killed enemies (yuko) were fed to symbolic and cannibalistic enemies such as the sun (see Halbmayer 2004a), while dead humans (yukpa) should return to their human relatives. So the Yukpa case seems not to reflect an Amazonian transformation between humans and animals but (although lacking exogamic clans) comes close to a northwestern Amazonian conception about which Fausto (2007a, p. 501) wrote « there is an ideal of keeping each system closed, even at the level of exogamic clans: human souls should return to their ancestors" "houses" and be reborn as the same kind of person (Hugh-Jones 1979, p. 112; Wright 1998, pp. 200-203) ». Much effort is made by the Yukpa to support their own dead in joining their dead relatives and to prevent them from getting lost or becoming subject of any form of foreign consumption. The deceased are fed by the Yukpa and later their dead relatives. They are not eaten and they should not be eaten by third parties as this would cause their second and final death. Yet, before I characterize the phasing of the rituals surrounding death and examine the exhumation ritual of the Yukpa in more detail, I would like to describe the central elements of the voyage to the world of the dead as specified in Yukpa myth.

\section{THE JOURNEY TO THE WORLD OF THE DEAD}

The journey to the world of the dead as described by the Yukpa (Wilbert 1974, pp. 80-83; Armato 1988, pp. 17-19; Lhermillier and Lhermillier 1999; Halbmayer 
2001b, 2008), fulfils many general criteria of such narratives in the region (Cipolletti 1982). The journey is difficult and dangerous: " whoever loses their way, or fails to pass certain tests, never arrives in the realm of the dead; indeed, may even be annihilated. For the individual, the latter means ultimate death » (ibid., p. 62, my translation). In the course of the journey one's resolution is put to the test, one must choose between different paths, have the strength of will to avoid being distracted by certain beings (or to fight them), but also to have the prowess to overcome geographical obstacles (ibid., pp. 62-64). The Yukpa also have to demonstrate their knowledge of cultural techniques (especially basket weaving). The willingness of particular beings to assist a dead spirit on this journey may also be dependent on the deceased's previous behaviour towards them during their lifetime.

The general structure of this Yukpa myth is as follows: A woman's lover was killed. He appears to the woman mourning at his toromo ${ }^{12}$ as wind, since wind - especially small whirlwinds or fog - is to the Yukpa a visible sign of the presence of spirits of the dead. He instructs the woman to look only at his feet. His body is covered in dry leaves (Villmañan 1982, p. 22). The woman sees only his feet, i.e. his footsteps - the traces of the wind - on the ground. He persuades her to come with him, showing her the way as wind. She follows the noise of broken branches by means of which he points the way. On the way they sleep several times.

On the journey the deceased is threatened by various animals, must pass tests and has to fight battles. The following challenges are to be awaited:

- the toad kopirchu demands that the traveller weave baskets and fans. Whoever is incapable of this is sent down the wrong path, the path of the flies. Kopirchu refers to the dead as meritu ${ }^{13}$ and offers chicha made of its excrements which has to be abrasively rejected;

- the traveller must be fearless and battle masaya, a black species of wasp known for its painful stings;

- the traveller must kill ayin menucha, a nettling worm that burns the skin;

- taiyaiya must be bypassed. This is considered either to be a narrow canyon that can collapse on the traveller or large rotating stones, turning like millstones that must be traversed ${ }^{14}$. Wilbert $(1974$, p. 82) also describes it as « a great wall against which leaned a big cudgel. The young man (the deceased-EH) took up the cudgel and hit the wall until it gave way, yielding them passage. This wall is called taiyaiya. It borders the Land of the Dead. Only those dead whom Kopecho [the toad $-\mathrm{EH}$ ] has sent along the path of the righteous can break through this wall ».

Taiyaiya is followed by a great body of water, arirpa, that the deceased can traverse only with the assistance of a dog. The deceased takes hold of the dogs ear's and the dog swims across the sea ${ }^{15}$. But the dog only permits this, if the deceased treated dogs well when alive. The traveller then arrives in the land of the 
dead, where they must scale a mountain. This mountain is associated with the peaks of the Sierra de Perijá - and this is one reason why the Yukpa avoid the Paramo region and the peaks of the Techtari and Shikimo mountains.

In the land of the dead, the deceased are greeted by their relatives, the other dead spirits, with a maize beer feast. After some time, the woman who went alive into the world of the dead returns to the land of the living, having promised not to speak of what she saw. But during a festival, under the influence of maize beer, she breaks her promise and narrates what she experienced. Assuming her dead lover will now reject her, she commits suicide.

\section{CO-PRESENT WORLDS AND THE INVERTED VIEW OF THE DEAD}

The journey to the world of the dead is not only arduous and dangerous and the world of the dead is not only like that of the living. The dead have a different view of the world, the dead's world is an "inverted world " (Cipolletti 1982, p. 83). In this perspectivist conception, both the living and the dead consider themselves to be living people who, for the most part, cultivate the same way of life ${ }^{16}$. But they are afraid of one another and find their smell detestable and consider each other as " deads ». The dead live in a land with plenty of food, but what appears to the dead as maize is only grass to the living, what they see as a deer is only a rat for the living. In the same logic, for the living rotting and phosphorescent tree trunks are the houses for the dead in this world and red mushrooms on the dead wood are referred to as the dead's fires and hearths. Small wirlewinds passing a sandy place may be referred to as okatu, deaths spirit and on foggy days the Yukpa perfer to stay in the village and argue that the world is dangerous and producing fear.

Such perspectivist concepts (see, among others, Århem 1996; Stolze Lima 1999; Viveiros de Castro 1998) are among the Yukpa most pronounced and explicit not in relation to animals but in relation to the dead. The discontinuity between these two most human-like timescapes of the living and the dead is specifically evident in these heterogeneous perspectives. Collective rituals - such as the Yukpa exhumation ritual - aim to effect specific changes in these perspectives and to produce a synchronisation between these timescapes and thereby facilitate the necessary contact and transition between such worlds.

The Yukpa refer to such worlds as ovaija ${ }^{17}$. The first inhabitants of this world are accordingly called " ovaijajo », " those who were in this world " in contrast to those living in other worlds "kopatka ovaija " such as the skyworld, the underworld, or world of the dead across the sea.

Such worlds constitue spatial-temporal configurations which I have called timescapes (Halbmayer 2004b) in contrast to non-spatial notions of time. Non-spatial concepts of time are based on a discontinuous continuity, a 
relationship in which the continuous (linear and circular) progression of time is hierarchically superordinate to the discontinuity of passing temporal units (seconds, minutes, days...). These units are strung together linearly, tagged with meanings of before and after and largely independent of spatial concepts. By contrast in Yukpa cosmology temporality overlaps with aspects of spatiality. Timescapes are based on continuous discontinuities. Continuity in this case does not consist primarily of the continuous passing of discontinuous units but rather in the continuous coexistence of different, i.e. discontinuous, units of space-time. When discontinuity dominates over linear continuity, time is not just a unidirectional "arrow » pointing from the past to the future, but an agglomeration of co-existing « space-times » or timescapes.

Such co-existing timescapes are corresponding forms of an Amazonian multiverse and multiple worlds in Amerindian cosmology (Overing 1985, 2004; Halbmayer 2004b). In contrast to a universe, a multiverse is based on numerous co-existing timescapes and on the continuity of discontinuity between them. Transition and contact between these worlds in turn becomes a central and often ritualised moment.

\section{DEALING WITH THE DEAD}

The basic sequence of events in dealing with a dead body among the Yukpa and the associated festivities have been described by Reichel-Dolmatoff (1945), Venturello $(1947,1950)$ and Wavrin $(1953){ }^{18}$. Among the Yukpa, funeral laments often begin when the relatives are convinced that the dead's okatu spirit will not return, which is often at a point where a person is not yet physically dead (Wilbert 1974 , p. 59). But while physical death is anticipated in these acts of grief, the social and spiritual relationship with the deceased goes far beyond the actual moment of physical death.

When a person finally physically dies, only the closest relatives remain with the corpse. The news of death is transmitted across the valley, from one settlement to the other, by means of blowing a cow's horn, towachta, by several shots fired into the air (Lhermillier A. 1980, p. 323) or through shouting the message across the valley from one compound to the next.

Traditionally, the relatives will ensure that a toromo is built for the mummification of the corpse. This is a circular platform on which the body of the deceased is placed in a squatting position and wrapped in cotton cloth to then be completely covered with leaves. This protects the dead (as opposed to dead enemies) both from the rain and the sun, which is presumed to eat human flesh. Several fires are lit around the toromo. They burn for several days and serve to dry and smoke the body. At this time food is brought to the dead: men are provided with tobacco and their weaponry while women are brought their millstone for 
grinding maize. Today the dead are also given preserves, rum and other Western goods - at least symbolically by means of empty cans and images of rum bottles.

That they are offered food and fed is a visible sign of the fact that they are still considered part of the community. The key phases of the treatment of the dead can be summarised in the following seven points:

1. mummification of the body for about a week;

2. burial of the corpse within the house and the continued provision of food for the deceased. Often the house is burned down and a roof is built over the grave. The grave itself is a cavity lined with wooden sticks on which the corpse is laid in such a way that it does not come into direct contact with the soil. The grave is covered with more wooden sticks and a thin layer of soil;

3. abandonment of the burial site for a month up to several years ${ }^{19}$. After the funeral, the burial site is normally avoided. Very close relatives alone will approach the site. Others who may have an ambivalent relationship to the deceased will avoid the site because it is assumed that the deceased is also potentially dangerous in this phase. The dead are dangerous as long as the flesh is in a state of decay. In cases where a positive relationship prevailed between a living and a dead individual, intensive contact may be sustained through dreaming, which may, for example, result in the transmission of knowledge, of songs or the medicinal value of certain plants;

4. preparation and celebration of a maize beer festival during which the exhumation takes place;

5. storage of the corpse in the rafters of a relative's house after the feast;

6. a subsequent journey of the deceased through several houses of close relatives, which may last several years (see Reichel-Dolmatoff 1945, p. 50);

7. finally, the corpse is interred in a collective burial cave (shormu) ${ }^{20}$.

The first three steps are related with the burial, point four with the complex ritual of exhumation, points five and six with the presence of the dead in the village after the exhumation and the final disposal of the corpse is the last step. After the completion of this disposal, the dead are present in this world primarily in non-personalised forms of wind and fog - like among the neighbouring Wayuu (Perrin 1987).

Knowledge about the structure of these funeral rites has been maintained to this date, although it has been subject to the influence of the Christian mission and acculturation even in the most remote villages. It is increasingly the case that the bodies are no longer mummified and in many regions the rite of exhumation has been abandoned. In the 20 years that I have worked with the Venezuelan Irapa-Yukpa I was never once in a position to observe such an exhumation ritual. 


\section{The EXHUMation RituAl: EKanE EWATPO - THE DANCE FEAST OF THE DEAD}

It was only in March 2009 that I could witness the Ekane Ewatpo ${ }^{21}$ among the Columbian Iroka-Yukpa. For the Iroka-Yukpa this ritual continues to be part of mortuary practice. In the following I would like to present, on the basis of journal entries, a description of the exhumation ritual (point 4), as my wife and I witnessed it. Following the description of each phase I will present an interpretative synopsis based on the assumption that the internal structure of the exhumation ritual only reveals itself if the existence of the two co-present worlds of the living and the dead are used as a point of departure together with the concomitant transformative and perspectivist quality of the ritual.

\section{Arrangements and preparations}

\section{March 2009, Sunday}

We were at the house of Enoc, halfway between Codazzi and Resguardo Iroka ${ }^{22}$. Those present included, among others, Alfredo Peña, the Cabildo and thus official representative of the Resguardo Iroka with its 3000 residents. In the late afternoon he says that " next week» an exhumation would take place and asked if we would like to participate in it. This proposal results in much excitement; finally to be able to witness for myself a ritual that I knew of only from old descriptions and the stories of older Irapa-Yukpa informants. On the other hand I knew that such statements about when something would take place left much room for interpretation and that this by no means meant that the ritual would actually take place next week. But Alfredo made it clear that such an exhumation ceremony must always be carried out during a full moon, which limited the possibilities. Full moon was in the middle of next week.

\section{March 2009, Monday}

We meet Alfredo in Codazzi at the casa indigena ${ }^{23}$. He arrives riding his new motorcycle with designer sunglasses but no helmet and announces that the ceremony will take place on Wednesday.

\section{1 and 12 March 2009, Wednesday and Thursday}

Early in the morning we went to the home of Wilson, where we are going to meet. Alfredo comes by on the motorcycle and says that we have enough time. We (Susanne, my wife, and I) go to the market to buy some food, coffee and batteries. Back at Wilson's house, Alfredo comes with a pickup truck, its payload already full of Yukpa men, women and children, sacks, a chicken, pallets of beer cans and other goods. Where we were to sit, much less stow our backpacks, is a mystery. The journey into the mountains is appropriately uncomfortable. Susanne sits next to me on a car tire and tries in vain to put at least one of her feet down somewhere. I sit on one of three large petrol canisters. This is how we spent the next few hours, in the dust and sun on an uneven dirt road up 
the mountain until we stop a good bit above the house of Enoc, where we were only three days ago. Several men are already waiting with their mules. The baggage is unloaded, namely, a large 5 litre bottle of rum, four pallets of beer cans, the three big canisters of petrol and numerous sacks of various goods and our own bags. These goods were all provided for by Alfredo: as Cabildo he sponsors the festivities in the village of his wife's parents ${ }^{24}$. Alfredo explains that we will drive a little further up the mountain, since the path there was shorter and not as steep as it was here. One of Alfredo's wives will leave with the small mule caravan from here to the village.

From there it goes not only up the mountain but on the other side down again to St. Clara (nana itchpo), the centre of Resguardo Iroka. Here a family whose child is sick and was in Codazzi to go to the hospital is dropped off. Alfredo publicises the celebration in every hamlet on the way and invites everyone to participate. We stop in St. Clara for a while - it's really a hot day...

On the way back up to the ridge we pick up Alfredo's mother, father and other relatives. Others say they will come to the celebration in the evening. Up on the ridge, where a watia (non-indigenous) family lives, the truck stops; the key is given up for safekeeping and we continue on foot, first along the road and then, after about ten minutes, up a path that branches off to the left. A short climb and it is possible to look into the valley and the many small settlements. We are shown where Süchaye is located on the opposite mountainside. There the ceremony will take place. We walk along the ridge and approach the village from above. Our small group consists of Alfredo's parents, Alfredo himself, a young Yukpa girl in a denim skirt with her younger brother, three other Yukpa, Wilson, and the two of us.

Having reached the crest of the mountain, a beautiful view into the next valley and into Iroka territory reveals itself. We also see tetraji, the «three breasts » (tres tetas), at over $3500 \mathrm{~m}$ the highest mountains of the Sierra de Perijá. That what awaits us is anything but an everyday event first becomes evident when the group marching around Afredo's father, begins to call out a rhythmic « hüh » on every fourth step. Two-thirds of the way we pass an abandoned house where we stop for a short break. The necessary preparations are discussed and dancing sticks ${ }^{25}$ are made of bamboo. Alfredo makes one for his mother, for Susanne, and for me. The girl in the denim skirt has one made for her by her brother. The dancing sticks are wielded by the men as if they were weapons. They are held in the right hand, lifted up and dropped on the ground, the hollow bamboo emitting a deep sound. The women hold the stick with both hands as if it were a paddle, setting it right and left in turn on the ground, crouching slightly and stamping their feet rhythmically. Walking this way into the village, our steps are transformed into a dance. After the dancing sticks are completed, sükü are made, i.e. pan flutes. One of the Yukpa is sent to find the necessary materials. He returns after about 15-20 minutes with long grass stalks with finger-thick stems. Yukpa pan flutes consist of five pipes, with the shortest pipe in the middle. First, five pipes of the same size are made and then the length of each pipe is decided upon. The grass is cut and broken off. Before the first three and then the last two stems are tied together the sound of the flute is tested.

One of the pipes made with too narrow grass stalks was found to be no good and another was made of thicker stalks that could produce deeper tones.

A watia (non-indigenous man) passes by and stops to chat, but he is not invited to the ceremony. Later a young Yukpa comes by on a horse and says that we were being 
awaited in the village. This results in much activity in the group and we break camp quickly. We continue down the mountainside accompanied by the hollow thumping of the dancing sticks and the rhythmic « hüh » of the men. Still above the village, Alfredo points out a tangled bramble on an isolated ridge. This is the grave site. Alfredo says that it is forbidden to go there but that we could go to see what it looks like. He and the younger men come with me while Susanne, the girl with the denim skirt and Alfredo's parents wait.

The grave construction is crowned by a simple corrugated aluminum roof built just above the ground. Under it can be seen a mound of earth with a pan flute and a wasp's nest placed on it. Brambles and branches had been placed around the site earlier this day. "To make it more difficult to retrieve the corpse from the grave" as Alfredo explains. Sometimes much larger piles of shrubbery cover the grave, he says. Two broken pots that belonged to the deceased lie beside the grave, as does a fork and an empty water bottle. These are the rests of the dead's personal belongings that were destroyed here.

We finally make our way down to the village. The people and the children observe us as we pass the first huts that lie just outside the village. Just before we reach the village proper we stop quickly and light cigarettes. Smoking is among the Yukpa also a means of spiritual protection. It is about five o'clock.

\section{The celebration's opening}

In the village itself we immediately make our way to the village plaza where we begin to dance without even stopping to put down our baggage. The men circle counterclockwise with their dance sticks and flutes, stomping their feet in a typical manner. Within this circle the women (Alfredo's mother, my wife Susanne, the girl with the denim skirt and, wearing a hat with long ribbons, Alfredo's wife, who had arrived with the mule caravan some time earlier) move back and forth on an east-westerly axis. Later the ajiwu-playing men of the village join the women in the centre of the circle ${ }^{26}$. The ca. $15 \mathrm{~cm}$ long ajiwu flutes that were once made out of human tibiae from dead relatives summon the spirits of the dead. The flutes have a single hole to change the tone and were once also called penanucha (Schön and Jam 1953, p. 74), meaning « the old ones ». They may only be played in this ritual and only by men. However no tabu on seeing these flutes applies. In the dancing in this initial phase of the ceremony the difference between village residents (ajiwu players) and guests (pan flute players) is more than clear, as is the difference between the dancers and the mourners, the music being accompanied by ever more and more wails from the mourners in the surrounding houses.

The two ajiwu players then take centre stage alone for at least thirty minutes (Figure 2), walking up and down, as they will do for the rest of the night, on an east-westerly axis (phase C, see the phases in Figure 8). One of the ajiwu players carries a new blanket on his back in which later the remains of the corpse will be wrapped. When one of the ajiwu flutes suddenly develops a defect, the dance is interrupted briefly and it is immediately repaired on the village square.

The other men then start to dance in a circle around the aijwu-players, intonating a loud « hui hü » in time to their dancing sticks and their stomping feet (phase D). 


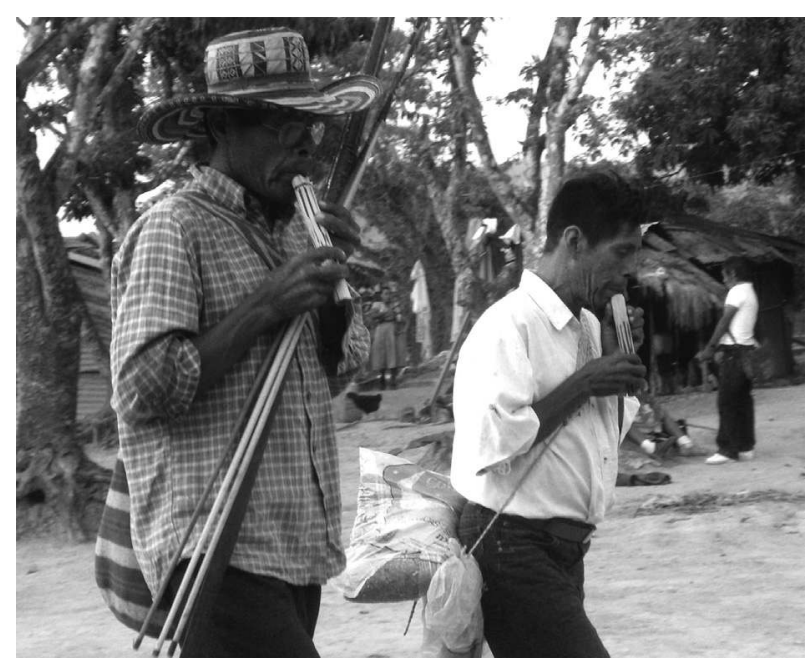

FIG. 2 - Dancers playing ajiwu.

In this time the guests are served something to eat and drink by the villagers (yuka and malanga with cheese).

Then the women return to the centre of the dancing circle with their dancing sticks to join the ajiwu players ${ }^{27}$. At least initially they dance and change direction out of sync with the latter. The men continue to dance their circles around the ajiwu players and the women. The point of departure of the dance as the opening of the ritual is thus complete. The differences between guests and the villagers have been resolved. This dance, in its rhythmic monotony, accompanied by the ajiwu flutes, will continue throughout the night to be danced until the early morning.

The next few hours will witness variations in the intensity of ecstasy, sorrow, anger and drunkenness but not in the dance. Whatever will happen in the night to come until the early morning, the step, the rhythm, will be maintained, sometimes by many, so that the village square will feel crowded and the ground will shake under the pounding feet, and then in the early hours between one and three o'clock in the morning by two or three lone, drunken and swaying figures.

Before nightfall, Alfredo's father will take up the ajiwu flute, holding his bow and arrows between his fingers. In so doing he will once and for all resolve the dichotomy of guests (pan flute players) and villagers (aijwu players).

Alfredo, the sponsor of the celebration, distributes packages of cigarettes to everyone, including the older children. Tobacco is a necessary ritual device; without it we would be exposed unprotected to the influence of the dead and the spirits of the dead. By seven o'clock it is pitch dark (the full moon will rise later). Many are dancing now, far more than before, when it was still light.

The celebration begins with the arrival of the guests on the plaza at the centre of the village. The guests from outside the village open the dance. The dance 
establishes a difference among the guests between men (dancing in a circle on the periphery and playing pan flutes ${ }^{28}$ ) and women (dancing in line on an east-westerly axis in the centre). Initially the dancers stand apart from their non-dancing hosts. The ajiwu players take the first step as a mediating category between guests and hosts. They are taken up at the centre of the dancing group of guests among the women and circled by men playing pan flutes. This is followed by a prolonged phase during which the two ajiwu-flute players dance alone, again on an east-westerly axis. In the meantime, guests and villagers talk in front of the surrounding houses, the former being served something to eat and drink. Then the men and later the women rejoin the dance without any differences between guests and hosts. The disparity between guest and host is thus resolved for the rest of the festival. Another dichotomy becomes central, namely that between celebrating dancers and grieving non-dancers, who stand outside the bounds of the village square and sob quietly.

\section{Leaving and re-entering the village}

After nightfall the men dance for the first time not only in a circle around the women and ajiwu players but out of the village. Having reached its border they turn around and return to the plaza (phases F-G).

Upon their return they are greeted with alcohol. No maize beer was made for this festival, as is usually the case. But as it turns out, in addition to the pallets of beer and the large bottle of rum, the three 40 litre petrol canisters were filled not with gasoline but a potent, homemade palm brandy that is now being served.

Where otherwise maize beer would have been served the dancers are given a sip of brandy without having to leave the circle. But the circle of dancers comes almost to a halt in an unintended queue before the dancing continues. This process is also repeated throughout night, and the dancing women in the middle are also repeatedly served some of the palm brandy. From time to time (first less, later more often) the surrounding onlookers are given alcohol as well. Even babies get to take a nip, their parents dipping their finger into the brandy to let the children suck on it.

Later, groups of men will generously distribute the brandy, browbeating the disinclined in no uncertain terms. This takes place with increasing frequency until after two to three hours (i.e. by between nine and ten o'clock) everyone is extremely drunk. Nevertheless the dance continues to the monotonous and entrancing rhythm.

While initially the guests (men and women) come from the outside to the village centre to be integrated into the community, as night fell the men leave the village while the ajiwu players and the women remain at the village plaza. The dancing of the men in particular traces the path of the deceased to the world of the dead. The dancers reproduce, as the Yukpa state themselves, the journey of the deceased in their dancing. With the coming of darkness the village is left by the male dancers, implying an initial separation between those remaining on the village plaza and the mourners, followed by their immediate return to the village, 
where they are greeted with alcohol. While during their first entry into the village the guests entered and occupied the plaza under the spiritual protection of tobacco smoke without being formally received by the villagers, now the entering dancers, including villagers and guests alike, are formally received and offered something to drink ${ }^{29}$. A transformation from foreign intrusion to formal reception has taken place.

\section{On the way into the land of the dead: dancers, mourners and ecstasy}

Aside the spectacle of the dance there are three houses where the close relatives of the deceased sit and lament loudly. The dancers become more and more ecstatic and the dancing men begin to leave the village square in ever increasing circles to dance around or through individual houses. They begin with the school, beating the supporting posts and the corrugated metal roof with their dancing sticks and bows.

The village teacher, exclaiming in fear that they will destroy all the buildings, runs to save the chalkboard, declaring that he does not have the money to replace it. The dancers stomp around the other houses, beating the posts and later the corrugated metal roofs. The mourners beat them off with sticks if they come too close or with lashes made of agave leaves.

There is always plenty of palm brandy to fuel the increasing state of ecstasy, interrupted only by the ever louder and more frequent lamenting. The behaviour of the dancers and onlookers on the plaza becomes increasingly aggressive and uncontrolled. The youths in particular behave more and more wildly. They throw a bucket at the dancers, who kick it away immediately. More guests are arriving, in the darkness, and the village is now really full. By 9:30 the atmosphere is so heated and the dancers are so intoxicated that we get the feeling that it is better retreat to the hut where we have hung our hammocks and follow the progress of the ritual from there. From the hut we have a good view of the goings on the village square.

The excessive alcohol, the rhythmic « hühs » and the pounding of the stomping feet intensify the ecstatic atmosphere; the dancers are doused with water and have dirt and later burning pieces of wood thrown at them. They beat on houses and tear off the corrugated metal roofs. The large pieces of metal are thrown across the square by the dancers and some of the onlookers. It is a miracle that no one gets hurt. Clothing that the dancers find in one of the houses suffers the same fate.

Despite this chaos, the dancers and ajiwu players continue their circling undeterred. After midnight the scene becomes calmer and the number of dancers decreases, many of them having fallen asleep, completely intoxicated and exhausted.

The relation of foreign intrusion is in this phase of the celebration re-enacted between the male dancers and the mourners in their houses. It takes places in an atmosphere marked by hours of continuous monotonous collective dancing, increased drunkenness and resulting ecstasy. The dance of the men re-enacts the path of the deceased, a fact that becomes most clear in this stage of the ritual. The relationship between the dancers and the onlookers not only articulates the concrete spatial-temporal relationships between the people present 
but in particular in the ritual relationship with co-present worlds and spiritual entities.

The movements in space, the repeated leaving of the village plaza, the circling and penetration of the surrounding houses is a concrete analogy to the contacts of the deceased to spiritual entities on their way to the land of the dead as they are described in the myth. This is the phase in which the dead must pass tests and complete tasks, must be fearless in their encounters with various spiritual entities on the journey to the land of the dead. It is the male dancers who are now more clearly than before on their way to the land of the dead and, despite all the adversities, overcome the beings they meet (the toad, the worms and the hornets) and drive them off. They are attacked by wild animals, have to overcome taiyaiya and knock down the aforementioned wall (Wilbert 1974, p. 82).

While the surrounding houses and people represent dangerous animal beings for the dancers, the living mourners drive off the " dancing dead » with sticks in an attempt to prevent their intrusion. The entire situation is an expression of the ritual's perspectivistic quality that goes far beyond the concrete persons present. It connects two different perspectives in a common frame of action. For the deceased as for the dancers, to persist and survive the trials and dangers posed by dangerous spirits and mourning villagers is the basic prerequisite for entering the world of the dead. The phases E1-H-I-E1 are repeated again and again.

\section{The welcoming celebration: trumpets, other music and changes in atmosphere}

Around two o'clock, several of the drunk youths begin playing plastic water hoses as if they were trumpets (phase $J$ ). They make as much noise as they can, waking all those who have fallen asleep - if need be by blowing the deep, long tones right in their ears. What they do here with plastic tubes was done traditionally with a cow's horn (towachta) or a large conch (see Lira 1989, p. 40ff). The sound of these instruments announces, among other things, the opening of a festival, informing the surrounding villages of this fact.

Scattered groups continue to dance to the ajiwu flutes until four in the morning. At times it appears that the dance will end, only to be continued with new energy. Many have fallen asleep again, others - extremely drunk - reel around uncontrollably, but the drinking continues.

At about four o'clock, after the younger men have thrown coals and fire everywhere - including into our hut and hammocks - the atmosphere changes suddenly (phase K). Another kind of music can be heard, cheerful and lively, harmonica and drum, the latter an empty petrol canister that once had contained homemade brandy. Everyone begins to dance again, but the structure of the dance is now another. The men no longer dance in a circle, the women no longer in a line with flute players. No ajiwu is played any longer. Instead, the men and women dance side-by-side in small loose groups. The youths have lost all their aggressive energy. The mourners who had earlier merely driven the dancers away from their homes now attack them on the plaza, beating them violently. I am asked by the dancers to take photos of happy, smiling faces and I am given something to drink. Soon the decision is made to go to the grave. 
The change in music and atmosphere marks the transition from the journey of the deceased to the welcoming celebration of the dead relatives for the deceased. The joyous festival being played out on the village square and announced by trumpets is this welcoming celebration of the dead for the deceased. The dancers and revellers no longer enact the perspective of the deceased, who is attacked and has to fight on his journey, but that of the dead celebrating in their village the arrival of their relatives in the land of the dead.

In this phase a synchronisation of the feast of the dead in the land of the dead and the living who take up the perspective of the dead takes place. A common ritual space is created between the worlds of the dead and the living. The living mourners who do not participate in this change of perspective however storm the plaza and intend to drive off the dead ${ }^{30}$.

\section{The exhumation: off to the grave}

Shortly after five in the morning it is finally time (phase L): we join a large group of people from the village on the path up the mountain to go to the grave. Halfway up we hear strange noises, trampling and snorting like that of heavily laden mules. It can be heard from quite far off. However, it is not an animal but the young Yukpa running past us up the mountainside, naked to the waist and smoking, enacting animals. They approach the dead not as humans but as animals. Running to the grave, they tear away the stacked branches and the roof to expose the mound of earth. What they do with the flute and the wasp's nest deposited there I do not know. Four, five, six bare-chested young men stand on the mound enacting armadillos and start to dig with their bare hands (phase M, see Figure 3).

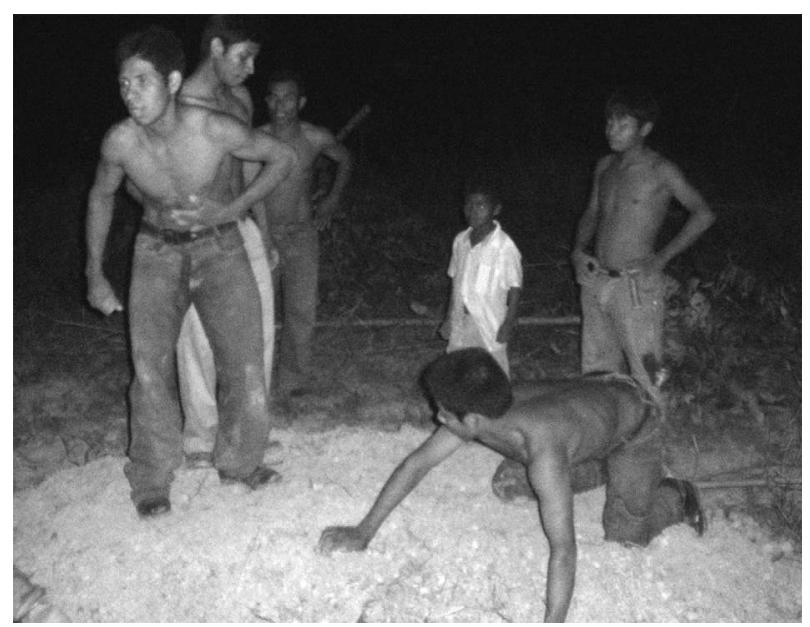

FIG. 3 - Young men on the grave of the deceased. 
The wailing of the mourners and the emotionality of the scene reaches it absolute climax; many of those present are tearful and upset. We wait until the whole train of mourners, the former ajiwu players and Alfredo have arrived, the new blanket in which the deceased will be wrapped spread over their heads. Alfredo has also taken off his shirt. As soon as the last group arrives, the digging continues with hands and sticks as if obsessed. One Yukpa, also with a naked upper body, starts tearing up the grass around the grave, driving off the onlookers sitting there. Another has fallen asleep on the middle of the path. Children have brought glowing embers along and in several places are setting the grass on fire.

Soon the hollow of the grave has been exposed and the remains of the cottonwrapped body has been retrieved. A few meters away from the grave it is laid on the new blanket. The people - men mostly - throw themselves on the corpse, weeping and lamenting loudly. Only a few young women have joined the group going to the grave and now sit as close to the body as they can, or they dance. The bundle is opened and the face of the young woman who died two months earlier is revealed. Her dried skin has taken on an extremely white tone, which is all the paler in contrast to her black hair. The howling, sobbing mourners touch her face, everyone tries one last time to make physical contact with her (see Figure 4). She is addressed in kinship terms (mostly piki, a very broad term that means, among other things, sister).

The dancing continues in the meantime and others play pan flutes; others again ask the onlookers for cigarettes or tobacco.

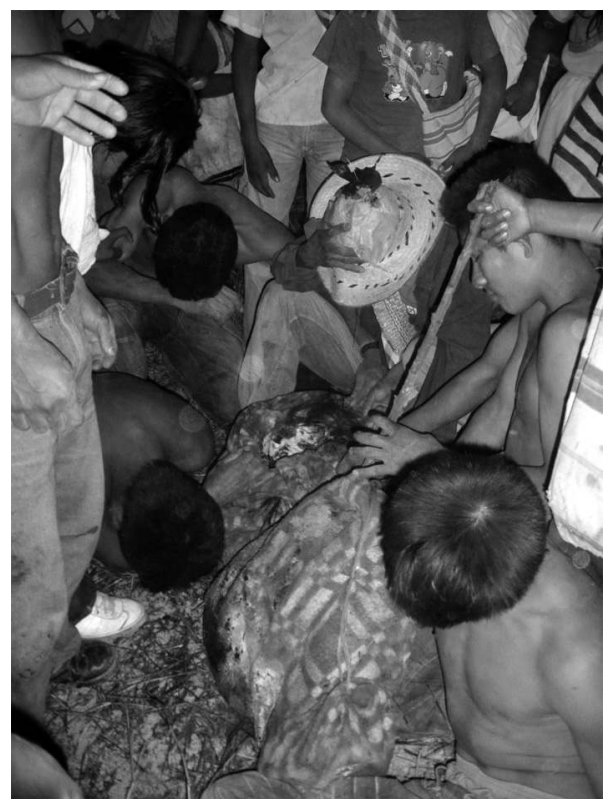

FIG. 4 - The bundle of the corpse and grieving Yukpa. 
The sun is slowly rising over the mountain ridge and some men wrap the body in the new blanket and try to tie it together. In view of their drunkenness it is not surprising that they do so with a great deal of difficulty. The mourners are sitting some distance away, weeping and lamenting the entire time. Eventually the men manage to tie the body of the deceased in the new blanket and fasten a carrying yoke to it.

An elderly Yukpa explains to us that they are good Yukpa and he can rely on his children to know exactly what to do at a Yukpa funeral. The idea that he will be buried « right» is a comfort for him.

One of the flute players - the one who was dancing with the blanket earlier - is the first to carry the bundle, the carrying yoke held on his forehead (phase M). The bundle is so heavy that three men alternate carry it back to the village. One of them is so drunk that he falls down immediately, and the bundle is taken up by another (Figure 5).

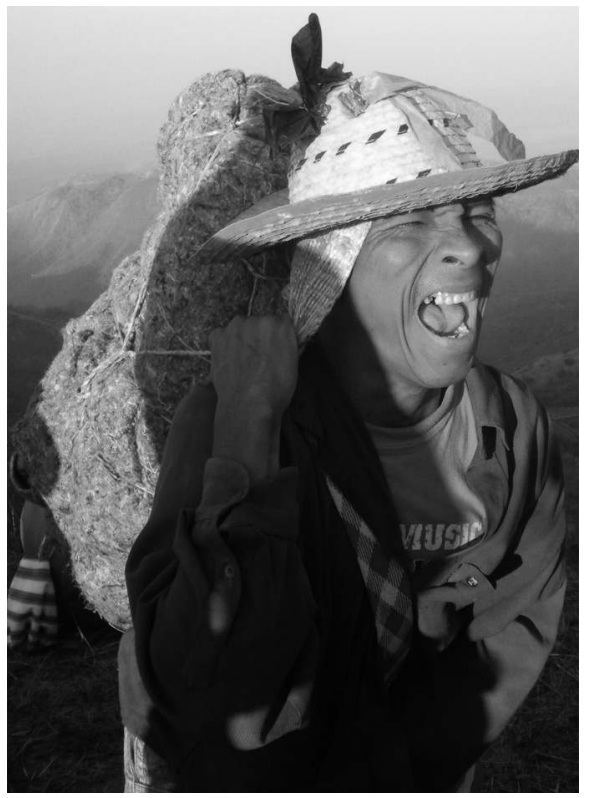

FIG. 5 - On the way to the village with the bundled corpse.

The Yukpa approach the grave as animals or as the dead. Those going to the grave are primarily men, among them the dancers and the ajiwu player we noticed at the very beginning of the celebration with the blanket in which the body is now wrapped. The path and the grave site is cleared by fire and by ripping out the grass. In numerous narratives it was repeatedly emphasised that the path should be clear, wide and free of undergrowth so that the deceased does not get lost and so that predatory entities cannot hide and easily attack them. The ajiwu player with the blanket is also the first to carry the body back to the village, and it is he 
who « knows » how and where to find the grave. His work is also referred to as achkú he, to steal. In the previous phases the Yukpa tried to avoid any predatory relationship to the deceased just as they try to prevent the deceased from becoming the victim of spiritual predation or to get lost on the way to the world of the dead and truly die. Nevertheless, from the perspective of the living this is not just a welcoming celebration, of the picking up and guiding of the deceased to the village of the dead. The protective relationship is now transformed into an act of robbery, a theft, on which the re-appropriation of the deceased is based. To successfully carry out such a theft, the grave is either approached as an animal or as the dead. Nevertheless, the perspective of the living is regaining in influence. It is no longer a joyful celebration. Grief and mourning, even among those who first danced, reach their full expression. In view of the real deceased and her corpse, the « dancing dead » quickly turn into « living mourners » who perform the theft and carry the deceased relative into the village. With the spatial distance and the new situation in the presence of the deceased, the perspectives of the celebrating dead and the living mourners become distinguished and in the land of the living the celebrants are transformed into mourners. While in the land of the living and the land of the dead the deceased is brought to the respective villages, this is done so from different perspectives. The retransformed mourners wail and steal the dead body to bring it to the village, while the dead of the land of the joyful dead accompany the living okatu to their village to celebrate.

\section{Return to the village: the captivation of the returnees and the appropriation of the deceased}

Most of the non-dancing mourners remained in the village, especially the older women. On our return into the village with the deceased, the dancing begins again almost immediately. The women rush to the carrier of the bundle and touch it, wailing loudly. They form a group around the deceased and moving as a group, dance across the village square. Some older women begin to dance with the returning men. Thus one of the older women comes up to me, hangs a basket of unknown contents from my forehead and dances with me. Somewhere a harmonica can be heard in the background. At the same time, those men who remained in the village seize the men returning from the grave and tie them up. Each one is tied with ropes and held for a few minutes (Figure 6). My wife Susanne and I are bound together and have to sing a song in order to be freed.

Soon the bundled corpse is on the ground and now the women weep and mourn the deceased. Just outside the village two young men begin a fight. They are separated but they attack one another again as soon as they can. Everyone is extremely drunk, many have fallen asleep again wherever they find a spot; one man is sleeping sitting on a pack-saddle.

Later, food is distributed again: unsalted soup with noodles, some rice and half-raw yuka. It appears that this meal was cooked by the children, the women for the most part being too drunk to cook. 


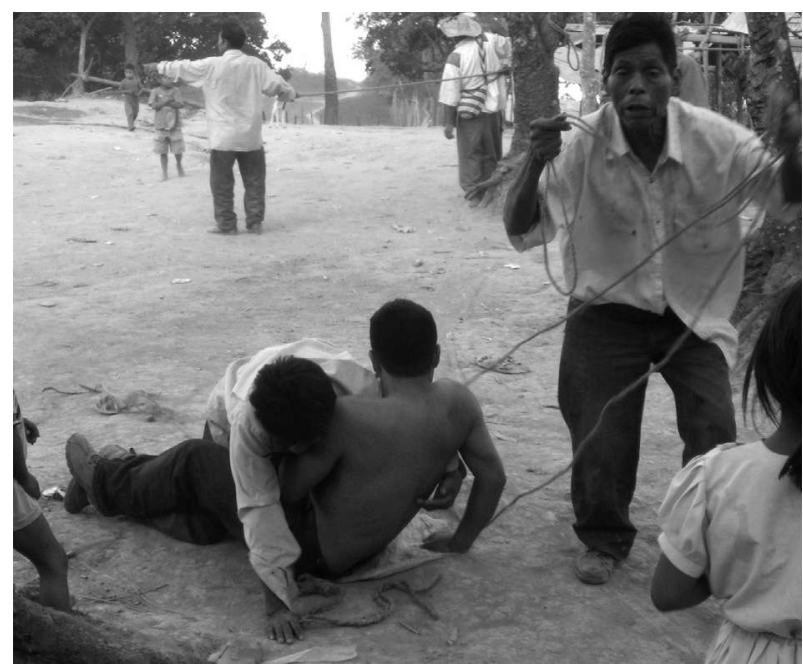

FIG. 6 - The captivation of the returnees.

A hush befalls the village. The corpse bundle is tied to a tree on the edge of the village square (Figure 7), where it will remain for several days before it is brought to one of the caves where the deceased will finally be laid to rest beside the other dead.

At about 11:30 Alfredo comes and announces that we must leave. The strenuous climb up the mountain to the pickup truck begins.

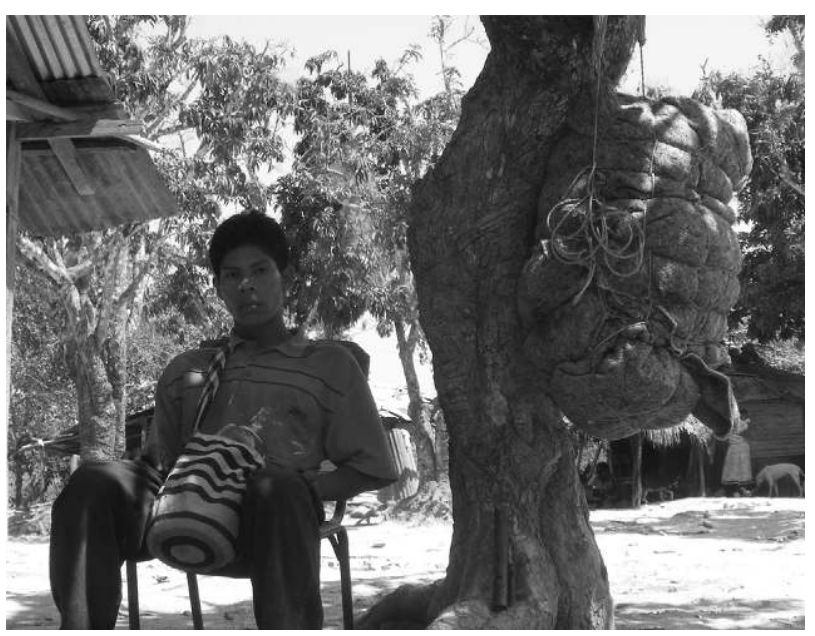

FIG. 7 - The dead remaining in the village after the celebration. 
Upon our return to the village, the non-dancing, grieving women who remained in the village begin to dance with the returning men and in turn appropriate the deceased. The expression of grief and emotion shown by the men at the grave is now shown by the women in the village square. At the same time, non-dancing and mourning men who have remained in the village overwhelm the former "dancing dead » and subdue them. Their arrest is also a form of punishment for the damage that the dancers have done in the village. However, it is not a real form of punishment, reparation or compensation, for the arrest is short and symbolic. Rather, the formerly "dancing dead » are arrested by male « mourners » who stayed in the village. While the women appropriate the corpse of the deceased the men appropriate the « dead », who, however, in the face of the deceased already have turned into human mourners. The prerequisite for their release is the affirmation of their human perspective and thereby the subjugation of the « dancing dead » to the world of the living is completed. This arrest is in and of itself an appropriation, an expression of the perspective that is now dominant. It is the common perspective of the living that prevails again. Just as the dancing dead have taken possession of the corpse, so do the mourners that remained in the village now take possession of the dancing dead and the corpse. The months-long separation of the mourning close relatives, who had to observe various tabus, and were thereby separated from the rest of the population ${ }^{31}$, thus comes to an end.

The final deposition of the corpse, which took place according to our informants about a week after the "de-burial », could not be observed. The corpse is placed in a cave or a place covered by a rock, which has to be dry so that any putrification of the dried flesh or rotting of the bones will be avoided. The corpse is carried to this place by a few close relatives and does not involve collective feasting or celebrations.

\section{CONCLUSION: THE RITUAL SYNCRONISATION OF CO-PRESENT WORLDS}

Once a living member of the community, a deceased person becomes a - still living - member of the community residing alone in a grave outside the village, while its spirit is on a dangerous journey to the land of the dead. In the described ritual, the living recreate this journey to the world of the dead, including the associated hazards and thereby create a ritual synchronisation of the two co-present worlds of the living and the dead.

At the same time they reproduce the differences between the living and the dead among the living within the ritual. It is the performative staging of these differences that permits the living to approach the deceased and allows for their re-appropriation. Only at the end of the ritual, in the face of the corpse of the deceased, do the dead living take on the human perspective of the bereaved, while 


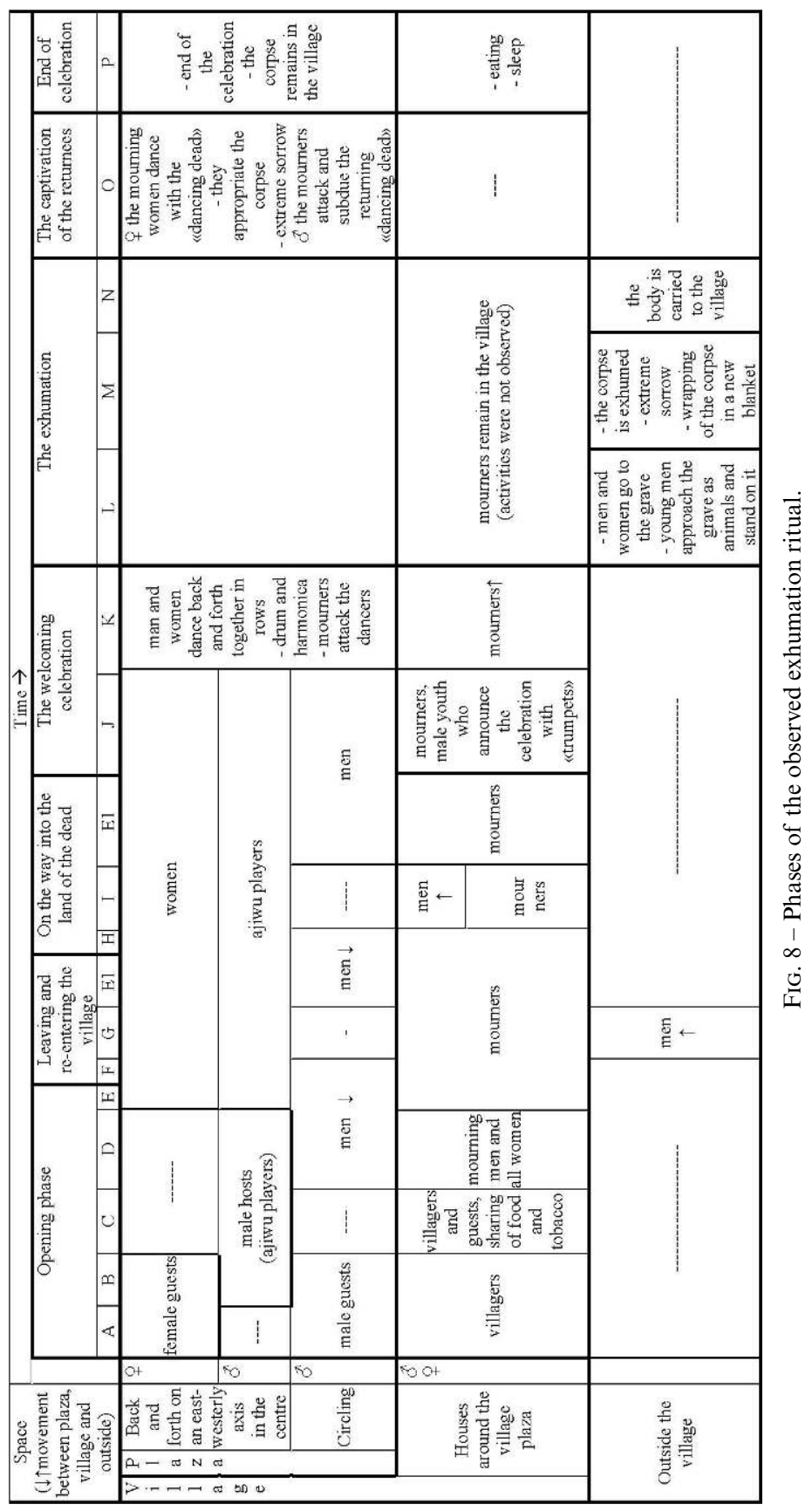


her spirit is welcomed in a celebration in the land of the dead. This marks the end of the deceased's personalised spiritual existence in this world.

The re-appropriation of the dead is thus incomplete, including only the physical remains of the corpse. The spiritual aspect of the deceased is, by contrast, received in the land of the dead with a welcoming celebration, at which point the deceased becomes a living being among the deceased relatives in the world of the dead. The appropriation by the living and their welcome by the dead leads to a double existence of the deceased in this world and the world of the dead. This doubling resolves the liminal and ambivalent intermediate phase, where the deceased unites in this world both aspects in itself. A transformation takes place from an ambivalent " in between » to a dual existence.

While the collective appropriation of the dead body is temporary, its spirit becomes a permanent resident of the land of the dead. It is only after the ritual described here that a body arrives at its final destination in the collectivity of the dead in a collective grave in the vicinity of the village, reproducing the separation of the dead and living in this world.

Thus, with regard to the transition from one world to the other, among the Yukpa neither does a radical separation between the dead and the living take place nor does there exist an unbroken continuity. Rather, we are dealing with a gradual and enduring transformation between co-present worlds and the concomitant perspectives. A transformation from the single existence of the living to a dual existence of the dead takes place mediated by the ambivalent « in between $\gg$ existence of the deceased.

The exhumation ritual writes fast the last break with the earthly existence of the personalised soul of the deceased, who has now arrived in the land of the dead to be reunited with deceased relatives to live, celebrate and dance. The aim of the Yukpa is not to establish and maintain a permanent line of communication or a relationship with personalised ancestors, but to allow the deceased an adequate and worthy life in the land of the dead.

By means of the perspectivist character of the ritual, a temporary synchronisation of the world of the living with the world of the dead is realised. At the same time a continous discontinuity is expressed and defended toward other co-existing timescapes of predating animals and dangerous spirits. The ritual is the interface of two co-existing timescapes, based on a temporary transformation of the participants in the ritual, not their permanent metamorphosis (see also Monod Becquelin 1982). The ritual is reducing the discontinuity toward the world of the dead by enacting and reproducing the difference between the dead and the living among the living. Thereby, a joint frame of reference with the largely analogous world of the dead is created and a gradual approximation performed. The celebrating living only take on the perspective of the dead with respect to the grieving living; in relation to the dead they remain alive. This also reduces the danger inherent in such ritual contact, that is, a real transformation of 
the living into the dead. The necessary discontinuity between the living and the dead is maintained while at the same time, through the synchronisation of the two worlds, contact and continuity are enabled.

The only individual who is de facto between the living and the dead is the deceased, for whom the ritual is being held. For him alone the ritual represents a final metamorphosis and not just a temporary transformation. This metamorphosis takes place on three levels, in each case an expression of the difference between the living and the dead. On the level of the ritual, the still living deceased, who has been excluded from the community of the living, is reintegrated into the community. In this world the deceased is not - as before the ritual-excluded from the community in an individual grave, but temporarily reintegrated into the village to find a permanent place in the collective burial site - the village of the dead in this world. At the same time the final metamorphosis between the two co-present worlds establishes a dual existence of the deceased, both in the village of the dead in this world and simultaneously in a new life in the land of the dead.

This ritual thus marks the final discontinuity to the earthly spiritual existence of the deceased and, at the same time, the most intimate, collective, repeatedly staged form of continuity with the dead as part of joint celebrations, dancing and drinking. It not only ensures human dignity at the end of life, but guarantees a new life, preventing the ultimate death of the deceased, if not in this then in an analogous and co-present world (Figure 8). *

* Manuscrit reçu en mai 2011, accepté pour publication en mai 2012.

\section{Notes}

This paper was translated by Andreas Hemming.

1. I want to thank Martha and Enoc Clavijo, Alfredo Peña and his parents, and Wilson Largo and his familiy for their friendship and support during our stay among the Iroka Yukpa. On the Caribspeakers, see Halbmayer (2010).

2. The following data on the Yukpa, their perception of death and death rituals were collected in several field studies between 1989 and 2009. Various Yukpa sub-groups numbering at least 14000 persons live in northwestern Venezuela and northeastern Columbia in the mountains of the Sierra de Perijá. On the classification of the Yukpa into sub-groups see Ruddle (1971) and Cariage (1979) as well as Halbmayer (1998). Today many Venezuelan Yukpa also live in larger cities such as Machiques and Maracaibo, the latter the second largest city of Venezuela. In Columbia, on the other hand, only few Yukpa stay permanently in Valledupar and other, smaller Columbian cities like Codazzi and Becerill. The Yukpa are thus integrated to different degrees and in different ways into the respective national and global societies. Whereas some live in urban environments, others continue to inhabit the isolated heights of the Sierra de Perijá.

3. These accounts focus very pragmatically on what is done (we make maize beer, we play ajiwu, a flute, we go to the grave, etc.). What these individual activities mean, the reason why one does these things, is touched upon only rarely. Detailed descriptions of specific aspects of the performance are also rare. Like in many such routines, only what one does is verbalised without going deeper into the meaning behind these obvious, and in the eyes of the actors, often banal facts. 
4. As mentioned before, the final disposal could take place several years after the « de-burial», the bones « travelling » through the houses of different relatives. Sometimes the final disposal does not take place at all, people living for decades with the bones stored in or near their house.

5. On this widespread motif see also Roth (1915, pp. 150-151), Goeje (1943, pp. 117-118), Lévi-Strauss (1964, pp. 165-171, 197-202), Hugh-Jones (1979, chap. 5), Viveiros de Castro (1992, pp. 211-212).

6. The theme of revitalisation and renewal via the application of life-giving liquids, be it in the form of washing oneself, as a neonate in the world of the dead or as an initiate, is widespread and can be found, for example, among the Carib-speaking Yekuana as well. In contrast, the Kalapalo assume that one is nursed in the land of the dead and hence ingests the life-giving liquids. The Wayuu, neighbours of the Yukpa who also conduct secondary burials, wash the bones of the dead.

7. This is closely related to the « soul » concepts of other Carib-speakers such as ekaton (Pemon), ekatï (Waiwai), ikatonbe (Makushi), akatu (Yekuana), akaton (Kariña) or akua (Kalapalo). Its meaning is often associated with "double» (aka means «two" in Yekuana) and it encompasses the spiritual qualities or « soul » of the person. On the problematic application of the eurocentric « soul » concept see Mader (2002).

8. On such examples found among Carib-speaking groups, see Halbmayer (2010).

9. For a historical contribution about Yukpa mummies including funeral masks see Sotomayor and Correal (2003).

10. Endo-cannibalism as found among the Wari (Conklin 1993, 1995, 2001; Vilaça 1992, 1993, 2000), the Yanomami (Clastres and Lizot 1978) and the Pano-speakers (Dole 1974; Erikson 1986; McCallum 1999), or exo-cannibalism such as among Tupi-Guarani-speaking groups (Fausto 2007b; Viveiros de Castro 1992).

11. This seems to be a distant version of the idea formulated among others by Sahlins (1978) to explain Aztec human sacrifices and their connection to cannibalism: these nourish the gods (the sun) and without them the universe would come to an end. For an analysis of the myth in which the sun appears as a hunter and consumer of humans see Halbmayer (2004a).

12. The platform on which a body is stored and dried for the first few days after death.

13. My informants did not offer a more specific meaning of this term. However, among the Carib-speaking Kapon and Pemon, meruntó refers to life-force, power or energy animating the material body (Butt Colson 1989, pp. 55, 86; Butt Colson and Armellada 1990, pp. 15, 26).

14. Cipolletti (1982, p. 68) refers to this as the Symplegade motif in allusion to the clashing rocks of the Bosphorus that the Argonauts of Greek mythology were required to navigate.

15. On the dog as a spiritual guide (psychopompos) in South American myths see Cipolletti (1982, pp. 63, 221). Among the Yukpa the black curassow (pauji) can also fulfil this function.

16. Although one does not sleep in the world of the dead.

17. This world humans live in was created in a mythical act by the culture hero Armouritsha, who transformed an undifferentiated, primordial condition on earth. Ovaija was uninhabited and uninhabitable: there were two suns, it never became dark and it was incredibly hot. The water on earth boiled like in a pot over a kitchen fire. Armouritsha transformed this world by changing one of the suns into the moon and thereby established tempered and liveable conditions based on a series of elementary distinctions, like day and night, hot and cold, and dry and wet. But space was also transformed: while changing one of the suns into the moon, Armouritsha raised the firmament, which until then had been very close to earth, and thereby he established the space called ovaija.

18. Acuña (1998) attempted to reconstruct the dance of the dead performed during the exhumation. The reconstruction however remained fragmentary and incomplete.

19. Statements on how long vary significantly both between Yukpa informants as well as in the literature. Traditionally the period of time is dependent on the availability of maize to sponsor the feast, nowadays it also depends on money for buying supplies and alcohol. There are also regional differences. Among the Iroka the exhumation generally takes place a few months after the death, while among the Irapa-Yukpa it takes place after a year or even longer. 
20. Wooden coffins in the form of boats for children were also deposited in these caves, as it appears, to ensure that they successful cross arirpa, the water separating the world of the dead from that of the living. Tio-tios, mnemonic devices, were also found in these coffins with images of the route to the world of the dead (Vareschi 1959, p. 74). For the use of tio-tio among the living see Lhermillier and Lhermillier (1982), Schön and Jam (1953, p. 75).

21. Ekane corpse, ewá to dance/to celebrate and -tpo a nominalizer.

22. Resguardos are the official indigenous administrative units. To my knowledge, this rite is today only practised within the Resguardos Iroka and Menkwe in Columbia.

23. Indigenous houses built in the cities. Indigenous travellers can stay here when visiting the city.

24. Such sponsoring is the discretionary allocation of public funds for community activities by the Cabildo. It takes place in the context of existing social and kinship relations and secures and legitimates the position of Cabildo.

25. In the past it appears that women alone used such dancing sticks; the men used their bows. Alfredo's father, who had his bow and arrows along, did not make such a stick. The sticks are traditionally decorated with markings that Bolinder (1925, p. 214) claimed represented the « legs of the dead ». Reichel-Dolmatoff $(1945$, p. 85$)$ calls this ritual staff mané:ra-čaya which suggests an association with the maneratcha tree, the wood of which was originally used to make these staves. The culture hero Amourisha carved the first Yukpa from the wood of this tree (Halbmayer 2004b). Reichel-Dolmatoff (1945, p. 54) interprets the symbols that Bolinder claimed represented the « legs of the dead » as snakes emerging out of a male triangle or a female rhombus.

26. Their joining the dance marks the transition from phase A to phase B. The Yukpa stress that the ayibu-players do not hold a close kin-relationship to the dead and her family. They are rather chosen on the basis of experience and knowledge.

27. Marking the transition from phase $\mathrm{D}$ to phase $\mathrm{E}$.

28. The pan flute is, according to the Irapa-Yukpa Jorge Pekare, associated with the jaguar and the toad. Lira (1989, p. 25) cites the following statement made by Pekare: « Cuando el tigre era gente, como persona, el tigre tocaba eso, y el sapo también; el tigre comenzó a practicar, para aprender a tocar de Tuano Neto, que eran los Poderes del Mundo ".

29. The difference between phase $\mathrm{E}$ and the following phase $\mathrm{E} 1 \mathrm{is}$ in the fact that in the first case no alcohol is served while in the latter it is.

30. The phases H and I may be repeated within the phase J, which may be followed by the phase E1.

31. The restrictions refer primarily to food exchange between the close mourning relatives and the rest of the community and to the sexual tabu of the widow or the widower. Whereas the first were strictly observed only during the first several weeks after the dead, sexual activity could be resumed by the widow or widower only after the exhumation ceremony.

\section{REFERENCES CITED}

Acuña Delgado Ángel

1998 La Danza Yu’pa. Una interpretación anthropólogica, Abya-Yala, Quito.

ÅrHEM Kaj

1996 «The cosmic food web: human-nature relatedness in the Northwest Amazon », in Philippe Descola and Gísli Pálsson (eds), Nature and society: anthropological perspectives, Routledge, London, pp. 185-204.

Armato Javier (ed.)

1988 Lo que cuentan los yukpa, Comisión Presidencial para el Bicentenario del Natalicio del General Rafael Urdaneta, Maracaibo. 
BARLEY Nigel

1981 "The Dowayo dance of death », in Sally C. Humphreys (eds), Mortality and immortality: The anthropology and archeology of death, Academic Press, London, pp. 149-160.

BLOCH Maurice and Jonathan PARRY (eds)

1982 Death and the regeneration of life, Cambridge University Press, Cambridge.

BOLINDER Gustaf

1925 Die Indianer der tropischen Schneegebirge, Strecker und Schröder, Stuttgart.

Butt Colson Audrey

1989 «La naturaleza del Ser. Conceptos fundamentales de los kapón y pemón », in Juan Botasso (ed.), Las religiones amerindias: 500 años después, Abya-Yala, Quito, pp. 53-90.

Butt Colson Audrey and Fray Cesáreo de Armellada

1990 «El rol económico del chamán y su base conceptual entre los Kapones y Pemones septentrionales de las Guayanas », Montalbán, 22, pp. 7-97.

Cariage Pierre

1979 Contribution à l'étude des Yuko: un groupe indigène du Nord-Est de la Colombie, doctoral thesis, École des Hautes Études en Sciences Sociales, Paris.

Carneiro da Cunha Manuela

1976 «Espace funéraire, eschatologie et culte des ancêtres: encore le problème des paradigmes africains", Actes du XLII Congrès International des Américanistes, 2, Société des Américanistes, Paris, pp. 277-295.

1978 Os mortos e os outros. Uma análise do sistema funerário e da noçâo de pessoa entre os índios Krahó, Hucitec, São Paulo.

ChaumeIl Jean-Pierre

1997 «Les os, les flûtes, les morts. Mémoire et traitement funéraire en Amazonie », Journal de la Société des Américanistes, 83, pp. 83-110.

2007 "Bones, flutes, and the dead: memory and funerary treatments in Amazonia », in Carlos Fausto and Michael Heckenberger (eds), Time and memory in Indigenous Amazonia. Anthropological perspectives, University Press of Florida, Gainesville, pp. 243-283.

Cipolletti Maria Susana

1982 Jenseitsvorstellungen bei den Indianern Südamerikas, Reimer, Berlin.

Clastres Hélène

1968 «Rites funéraires guayaki », Journal de la Société des Américanistes, 57, pp. $63-72$.

Clastres Hélène and Jacques Lizot

1978 «La muerte y la idea del canibalismo entre los Yanomami », Boletín Indigenista Venezolano, 18, pp. 107-142.

Conklin Beth A.

1993 "Hunting the ancestors: death and alliance in Wari' cannibalism », Latin American Anthropological Review, 5, pp. 65-70. 
1995 " "Thus are our bodies, thus was our custom": mortuary cannibalism in an Amazonian society », American Ethnologist, 22, pp. 75-101.

2001 Consuming grief: compassionate cannibalism in an Amazonian society, University of Texas Press, Austin.

Dole Gertrude E.

1974 «Endocannibalism among the Amahuaca Indians », in Patricia J. Lyon (ed.), Native South Americans. Ethnology of the least known continent, Little, Brown and Company, Boston, pp. 302-308.

ELIADE Mircea

1949 Le mythe de l'éternel retour, Gallimard, Paris.

ERIKSON Philippe

1986 " Altérité, tatouage et anthropophagie chez les Pano: la belliqueuse quête du soi », Journal de la Société des Américanistes, 72, pp. 185-209.

Fausto Carlos

2007a «Feasting on People. Eating Animals and Humans in Amazonia », Current Anthropology, 48, pp. 497-530.

2007b «If God were a jaguar: cannibalism and christianity among the Guarani (16th-20th Centuries) », in Carlos Fausto and Michael Heckenberger (eds), Time and memory in Indigenous Amazonia. Anthropological perspectives, University Press of Florida, Gainesville, pp. 74-105.

GoEJe Claudius Henricus de

1943 «Philosophy, initiation and myths of the Indians of Guiana and adjacent countries ", Internationales Archiv für Ethnographie, XLIV, pp. 1-136.

GoODY Jack

1962

Death, property and the ancestors: a study of mortuary custom among the Lodagaa of West Africa, Stanford University Press, Stanford.

HALBMAYER Ernst

1992a Erzählungen von Raphael Iroka, sound recording from 25/3/1992, Austrian Phonogrammarchiv, coll. «Halbmayer » D 6483, Vienna.

1992b Nupe und Theresa: Erzählungen, sound recording from April 1992, Austrian Phonogrammarchiv, coll. « Halbmayer» D 6561, Vienna.

1998 Kannibalistische Sonne, Schwiegervater Mond und die Yukpa, Brandes \& Apsel, Frankfurt/Main.

2001a Wie die Schlangen, der Skorpion, die Grille, die Küchenschabe ihre Haut ablegen und zu einem neuen Leben kommen, sound recording from 6/1/2001, Austrian Phonogrammarchiv, coll. « Halbmayer» D 2118, Vienna.

2001b Reise ins Totenland, sound recording from 5/1/2001, Austrian Phonogrammarchiv, coll. « Halbmayer » D 2114, Vienna.

2004a «Elementary distinctions in world-making among the Yukpa », Anthropos, 99, pp. 39-55.

2004b "Timescapes and the meaning of landscape: examples from the Yukpa ", in Ernst Halbmayer and Elke Mader (eds), Kultur, Raum, Landschaft: Die Bedeutung des Raumes in Zeiten der Globalität, Brandes \& Apsel, Frankfurt Main, pp. 136-154. 
2008 "Meanings of suicide and conceptions of death among the Yukpa and other Amerindians of Lowland South America ", Curare. Journal of Medical Anthropology, 31, pp. 72-86.

2010 Kosmos und Kommunikation. Weltkonzeptionen in der südamerikanischen Sprachfamilie der Cariben, Facultas Verlag, Wien.

HeRTz Robert

1907 «Contribution à une étude sur la représentation collective de la mort », Année sociologique, 10, pp. 48-137.

Hugh-Jones Christine

1979 From the Milk River. Spatial and temporal processes in Northwest Amazonia, Cambridge University Press, Cambridge.

ILLIUS Bruno

1991 Ani Shina: Schamanismus bei den Shipibo-Conibo (Ost Peru), Lit Verlag, Münster.

KoHL Karl Heinz (ed.)

1992 Mythen im Kontext: ethnologische Perspektiven, Edition Qumran, Frankfurt/Main.

LÉvi-STRAuss Claude

1964 Mythologiques, 1. Le cru et le cuit, Plon, Paris.

LHERMILLIER Alex

1980 La société yu’pa-macoita de la Sierra de Perija au Venezuela, 1. Résistance et transformations des structures traditionnelles, École des Hautes Études en Sciences Sociales, Paris.

LHERMILLIER Alex and Nelly LHERMILLIER

1982 «Kano or Mak’â », Boletín Antropológico, 2, pp. 17-22.

1999 «El mito y el tiempo entre los yu’pa », Boletín Antropológico, 46, pp. 5-21.

LIRA José B.

1989 Yukpa Emai'k’pe (Aproximación al mundo musical Yukpa), Dirección de Cultura, Maracaibo.

MADER Elke

1999 Metamorfosis del poder. Persona, mito y visión en la sociedad Shuar y Achuar (Ecuador, Perú), Abya-Yala, Quito.

2002 "Seele", Kräfte und Personen. Spirituelle Dimensionen von Mensch und Natur in Amazonien », in Johann Figl and Hans Dieter Klein (eds), Der Begriff der Seele in der Religionswissenschaft, Königshausen \& Neumann, Würzburg, pp. 61-86.

MALINOWSKi Bronislaw

1929 The sexual life of savages in North-Western Melanesia, Harcourt, Brace \& Jovanovich, New York/London.

1948 Magic science and religion, Faber \& West, London.

McCallum Cecilia

1999 "Consuming pity: the production of death among the Cashinahua ", Cultural Anthropology, 14, pp. 443-471. 
Monod BeCQuelin Aurore

1982 «La Métamorphose», Journal de la Société des Américanistes, 68, pp. 133-147.

MüNZEL Mark

1994 «Geisterkultur: sind nun auch noch die Mythen postmodern? », in Birgit Scharlau (ed.), Lateinamerika denken. Kulturtheoretische Grenzgänge zwischen Moderne und Postmoderne, G. Narr, Tübingen, pp. 266-277.

OVERING Joanna

1985 "Today shall I call him "mummy": multiple worlds and classificatory confusion ", in Joanna Overing (ed), Reason and morality, Tavistock Publications, London/New York, pp. 152-179.

2004 "The grotesque landscape of mythic "Before Time"; the folly of sociability in "Today Time": an egalitarian aesthetics of human existence ", in Ernst Halbmayer and Elke Mader (eds), Kultur, Raum, Landschaft: Die Bedeutung des Raumes in Zeiten der Globalität, Brandes \& Apsel, Frankfurt Main, pp. 74-92.

PERRIN Michel

1987 The way of the dead Indians: Guajiro myths and symbols, University of Texas Press, Austin.

RADCLIFFE-BROWN Alfred R.

1964 The Andaman Islanders, Free Press, New York [1st ed. 1922].

ReICHel-Dolmatoff Geraldo

1945 «Los Indios Motilones », Revista del Instituto Etnológico Nacional, 2, pp. $15-115$.

RIVIÈRE Peter

1984 Individual and society in Guiana. A comparative study of Amerindian social organization, Cambridge University Press, Cambridge.

1993 "The Amerindianization of descent and affinity », L'Homme, XXXIII, pp. 507-516.

Roth Walter E.

1915 "An inquiry into the animism and folklore of the Guiana Indians », Thirtieth Annual Report Bureau of the Smithsonian Institution, pp. 103-386.

RuDDLE Kenneth

1971 "Notes on the nomenclature and distribution of the Yukpa-Yuko tribe », Antropológica, 30, pp. 18-28.

SAHLINS Marshall

1978 "Culture as Protein and Profit», New York Review of Books, 25 (18), pp. $45-53$.

SCHÖN Miquel and Pedro L. JAM

1953 "Cultura social», in La región de Perija y sus habitantes, Sociedad de Ciencias Naturales La Salle/Universidad del Zulia, Maracaibo, pp. 71-98. 
Sotomayor Hugo and Gonzales Correal

2003 «Las calaveras enmascaradas de las momias Yuko-Yukpa (Motilones)», Revista de la Academia Colombiana de Ciencias Exactas, Físicas y Naturales, 27, pp. 5-14.

Stolze Lima Tánia

1999 "The two and its many: reflections on perspectivism in a Tupi cosmology ", Ethnos, 64, pp. 107-131.

TAYLOR Anne Christine

1993 «Remembering to forget: identity, mourning and memory among the Jivaro », Man, 28 (4), pp. 653-678.

TURNER Victor

1969 The ritual process. Structure and anti-structure, Aldine, Chicago.

VARESCHI Volkmar

1959 Geschichtslose Ufer. Auf den Spuren Humboldts am Orinoko, F. Bruckmann, München.

Venturello Battista

1947 "Con los Indios Motilones de Colombia », Revista Geográfica Americana, XXVII (164), pp. 267-273.

1950 «El baile funerario en las tribus Motilones de Colombia », Revista Geográfica Americana, XXXIII, pp. 261-264.

VILAÇA Aparecida

1992 Comendo como gente: formas do canibalismo Wari' (Pakao-Nova), Editora da UFRJ, Rio de Janeiro.

1993 «O canibalismo funerário Pakaa-Nova: uma etnografia », in Eduardo B. Viveiros de Castro and Manuela Carneiro da Cunha (eds), Amazônia: etnologia e história indígena, Universidade de São Paulo, Núcleo de História indígena, São Paulo, pp. 285-310.

2000 «Relations between funerary cannibalism and warfare cannibalism: the question of predation », Ethnos, 65 (1), pp. 83-106.

ViLlamañan Adolfo de

1982 "Introducción al mundo religioso de los Yukpa », Antropológica, 57, pp. 3-24.

Viveiros de CASTRo Eduardo

1992 From the enemy's point of view, University of Chicago Press, Chicago.

1993 «Alguns aspectos da afinidade no dravidianato Amazônico », in Eduardo Viveiros de Castro and Manuela Carneiro da Cunha (eds), Amazônia: etnologia e história indígena, Universidade de São Paulo, Núcleo de História indígena, São Paulo, pp. 149-210.

1998 "Cosmological deixis and Amerindian perspectivism », Journal of the Royal Anthropological Institute, 4 (3), pp. 469-488.

2001 «GUT feelings about Amazonia: potential affinity and the construction of sociality ", in Laura M. Rival and Neil L. Whitehead (eds), Beyond the visible and the material: the Amerindianization of society in the work of Peter Rivière, Oxford University Press, Oxford, pp. 19-44. 
WAVRIN Robert (Marquis de)

1953 Chez les Indiens de Colombie, Plon, Paris.

WILBERT Johannes

1974 Yukpa folktales, University of California Press, Los Angeles.

WRIGHT Robin M.

1998 Cosmos, self, and history in Baniwa religion: for those unborn, University of Texas Press, Austin. 